\title{
South African public sector procurement and corruption: Inseparable twins?
}

\begin{abstract}
Author:
Pandelani Harry Munzhedzi ${ }^{1}$

Affiliation:

${ }^{1}$ Department of Public

Administration, University of Limpopo, South Africa

Corresponding author and email:

Pandelani Harry Munzhedzi harry.munzhedzi@ul.ac.za

Dates:

Received: 19 June 2015

Accepted: 03 Oct. 2015

Published: 03 Feb. 2016

How to cite this article: Munzhedzi, P.H., 2016, 'South African public sector procurement and corruption: Inseparable twins?', Journal of Transport and Supply Chain Management 10(1), Art. \#197, 8 pages. http:// dx.doi.org/10.4102/jtscm. v10i1.197

Copyright:

(C) 2016. The Authors.

Licensee: AOSIS.

This work is licensed under

the Creative Commons

Attribution License.
\end{abstract}

Read online:

Scan this $Q R$ code with your smart phone or mobile device to read online.
The article seeks to explore the relationship between procurement in the public sector and corruption. Corruption in the procurement process is one of the biggest challenges facing the South Africa government. Procurement in the South African public sector through the tendering process has been used with a particular aim of addressing the past discriminatory practices and policies by empowering the previously disadvantaged majority. It ought to operate within a certain legislative and regulatory framework. However, the article argues that in the process of implementing the good intentions of the government, corruption illegitimises the process. There are also challenges that are associated with public sector procurement, with corruption being the main protagonist. The article also seeks to suggest possible solutions that could be used to address the anomalies. The article further concludes that the main reason for the rife corruption in the public sector is that there is nonadherence to policy prescripts including the Public Finance Management Act, 1999 (Act 1 of 1999) and the Municipal Finance Management Act, 2003 (Act 56 of 2003). This enormous predicament may only be addressed if the government were to show will and commitment by punishing offenders who do not comply with the said legislative framework.

\section{Introduction}

The South African legislative framework underpinning public sector procurement aims at empowering the previously disadvantaged and provides flexibility to individual public institutions to facilitate efficient service delivery (Ababio, Vyas-Doorgapersad \& Mzini 2008:3). This is as a result of the fact that the predemocratic South Africa's procurement system was characterised by discrimination and prejudices that favoured the white minority and disadvantaged the black majority. To address this anomaly, the democratic government introduced a reform in the public sector procurement through a preferential procurement system to address the socio-economic objectives (Ambe \& Badenhorst-Weiss 2012:242). Procurement is deemed to be of particular significance in the public sector in that it has been used as a policy tool to address the discriminatory and unfair practices during apartheid (Bolton 2006). However, the laudable policy framework introduced is often grossly undermined by incidents of lack of accountability, political interference, appointment of inexperienced and unqualified officials and contractors, lack of technical expertise in the respective bid committees, lack of understanding of relevant regulatory framework and noncompliance with policy framework (Horn \& Raga 2012:80). All these stated challenges associated with public sector procurement are in one way or the other contributors to the dominance of corruption. The article posits that the South African public sector procurement and corruption are like inseparable twins in that they often cannot be separated. Whenever one of the two is mentioned, the other one has to follow in the next line.

\section{Conceptualising corruption}

Whilst corruption is a universal problem, it is particularly harmful in developing countries (Department of Public Service and Administration 2003:11). Webb (2010:673) also concurs that unlike in the developed world, developing states seem to be most vulnerable to corruption. Thornhill (2012) defines corruption as:

offering or granting, directly or indirectly to a public official or any other person, of any goods of monetary value, or other benefit, such as a gift, favour, promise or advantage for himself or herself or for any other person or entity, in exchange for any acts or omission in the performance of his/her public functions. (p. 140)

Simply put, corruption refers to an abuse of official authority with intent for personal advantage. The most common types of corruption include bribery, fraud and the misappropriation of economic wealth. The reason for this may be associated with the fact that the provision of services in the developing societies is reliant on the government. Without transparent and accountable systems, 
the vast resources channelled through public procurement systems run the danger of being entwined with increased corruption and misuse of funds (Jeppesen 2010). Mahlaba (2004) and Munzhedzi (2013:284) also posit that fraud and corruption cost South African tax payers hundreds of millions of rand each year. Greater management autonomy for public servants lead to excessive discretion and create opportunities for fraud and corruption as public managers are freed from traditional budgetary control measures (Douglas \& Jones 1996; Shamsul Haque 2001:72). Some scholars argue that the creation of a professional public service could reduce the incidents of corruption (Pope 2000:107-110; Rose-Ackerman 1999:69-70).

Klitgaard, Maclean-Abaroa and Lindsey-Parris (2000:24-29) remark that successful prevention of corruption requires public official's discretion to be limited and clarified, monopoly power to be reduced and transparency to be increased. Even though accounting officers (Director Generals in national departments, Head of Department in provincial administration, and Municipal Managers at the local and district municipalities) are mandated to take effective and appropriate disciplinary steps against any official in the public service institutions who contravenes or fails to comply with provisions of the financial prescripts or commits an act that undermines the financial management and internal control system of the department, there seem to be no success. The Public Finance Management Act, 1999 (Act 1 of 1999) also states that the accounting officer should charge any official who makes or permits an unauthorised expenditure, irregular expenditure or fruitless and wasteful expenditure. The article argues that departments through their accounting officers have not been successfully executing this magnanimous role. Stapenhurst and Langseth (1997:311) argue for a holistic approach when reforming the public service, one that includes corruption prevention as a key consideration.

\section{Conceptualising procurement}

Public procurement in South Africa has been granted constitutional status and is recognised as a means of addressing past discriminatory policies and practices (Bolton 2006:193). Procurement is also central to the government service delivery system in South Africa (Ambe \& BadenhorstWeiss 2012:242). Procurement refers to the acquisition of goods and services at the best possible total cost of ownership, in the right quantity and quality, at the right time and in the right place generally via a contract (Ababio et al. 2008:10). Public procurement on the other hand refers to the government's activity of purchasing the goods and services needed to perform its functions inter alia service delivery (Arrowsmith 2010:1; Moeti 2014:141). Despite the reform processes in public procurement as a strategic tool, there are quandaries in the South African public procurement practices, including noncompliance with procurement legislative framework as well as tender irregularities. Corruption, incompetence and negligence by public servants' are some of the anomalies associated with public sector procurement (Ambe \&
Badenhorst-Weiss 2012:243). To give credence to this, the South African government spent R26.4 billion in 2010 in ways that contravened laws and regulations including corruption (Smart Procurement 2011). Evidence shows that a huge chunk of government money ends up in corrupt activities often through the procurement process.

\section{The relationship between procurement and corruption}

A number of countries have become increasingly aware of the significance of procurement as an area vulnerable to mismanagement and corruption (Ambe \& Badenhorst-Weiss 2012:245). As part of the efforts to adopt a long-term and strategic view of their procurement needs and management, most countries have resorted to using their annual procurement plans as a possible problem solver (Mahmood 2010:103). The South African government has recently established the office of the chief procurement officer at the National Treasury to inter alia address challenges associated with government procurement (Gordhan 2014:28). Besides lack of capacity to deliver required services, lack of financial control systems and lack of political stability, one of the biggest challenges facing South African public sector particularly municipalities is corruption and maladministration (Thornhill 2006:322-323). Madumo (2012:50) concurs that corruption and maladministration exist in all the spheres of government in particular in the local sphere of government. However, this is also associated with the appointment of a senior administrative workforce, which is often influenced by political affiliation with a particular ruling party in that municipality or province (Reddy, Naidoo \& Pillay 2005:49-50).

More often than not, the said corruption ensues during the process of procurement of goods and services. It is either that the prices are inflated, contracts are awarded to friends or family, tenders are not advertised, bid committees are not properly constituted or that panel members did not declare their interest before the sitting of the adjudication committee. Moeti (2014) posits that to a certain extent, most fraud and corruption in government occurs through poor procurement management and control. To this end, it is safe to argue that the relationship between public sector procurement and corruption is inevitable. It seems as though one cannot exist without the other. The two are like inseparable twins in the context of South Africa. This is often associated with the fact that supply chain management (SCM) (of which procurement forms a part) has been decentralised to individual provinces, municipalities and public entities, which may lack skills and capacity.

\section{Centralised versus decentralised public procurement}

The democratic government in 1994 inherited a model of procurement, which was centralised in that the tendering process was managed by the Department of State Expenditure (Moeti 2014:143). The disadvantage with this process though is that there was an administrative 
delay and a cumbersome process. As a result, government amended the State Tender Board Act, 1968 (Act 86 of 1968) so as to empower the accounting officers (Director Generals, Provincial Head of Departments, Municipal Managers, and Chief Executive Officers of municipal entities) to manage their own tendering process. It is in this decentralisation that several challenges occur, including lack of skills and capacity, noncompliance with policies and regulations, lack of accountability and corruption (Ambe \& Badenhorst-Weiss 2012:250-251). However, those in favour of centralisation argue that the government may save a reasonable share of unnecessary costs by buying in bulk. This may be because of the fact that most government institutions need more or less the same goods and services, namely, desktops, laptops, photocopy machines, furniture and stationery. Centralisation of procurement eliminates duplication of efforts in that there may be only one or two bid committee, bid administration unit and bid adjudication committee. These committees may manage all procurement processes of government in its entirety or at least for the whole province, particularly for huge procurements. Bid committee refers to a committee responsible for consideration of bid submissions and it often consists of not more than three people of which one must come from the SCM unit (Khalo 2014:229). Adjudication committee considers recommendations from the bid committee and makes the final award depending on the delegated powers, whilst the bid administrative unit provides administrative support to the bid committee. Khalo (2014:229) indicates that the administrative support referred to includes advertisement for bids, opening of bids, announcement of bids and communicating adjudication outcomes.

However, those who argue for decentralisation purport that the state tender board was far removed from suppliers of goods and services and that there was often little communication between decision makers, potential service providers and those in need of such services (Moeti 2014:144). They argue that individual managers at various government departments, municipalities and entities are better placed to take efficient decisions regarding the appointment of service providers. Pauw et al. (2002:241-242) are of the opinion that decentralisation is advantageous for the following reasons:

- Local managers gets a sense of greater authority in terms of making decisions regarding best products choices, better services from suppliers, and receipt of value-formoney.

- Enhances performance and accountability of accounting officers.

- Transparency in procurement is more likely.

- Minimises failures by enhancing internal controls.

The foregoing reasons indicate that Pauw et al. (2002) encourages the decentralisation of procurement in the public sector. They further argue that because of the said internal control at individual institutions, challenges such as fraud and corruption may be minimised. It is posited that centralisation is more associated with secrecy, autocracy and lack of transparency. However, the article argues that corruption has very little to do with centralisation or decentralisation, but with effectiveness and efficiency of the control measures employed.

\section{Legislative framework on procurement and corruption}

There are legislative and regulatory frameworks that outline minimum requirements in the areas of supply chain and preferential procurement. National departments and provincial and local governments are allowed to extend and develop their own individual policies, systems and structures within the ambit of the national regulatory framework (Hanks, Davies \& Parera 2008). However, to a large extent, public procurement is decentralised to the respective departments, provinces and municipalities. It is in this decentralisation that individual public sector institutions are vulnerable to mismanagement, fraud and corruption. In general, South Africa has a comprehensive legal framework to deal with corruption (Department of Public Service and Administration 2003:26). The National Treasury's regulation provides that organs of state should establish three kinds of committees, namely, bid specification, bid adjudication and bid award committees. Some departments have decided to combine the bid specification and adjudication committees (Pauw 2011). Some of the relevant legislative frameworks are discussed below.

\section{Constitution of the Republic of South Africa of 1996}

Section 217(3) of the Constitution of the Republic of South Africa of 1996 (hereafter referred to as the 1996 Constitution) requires that legislation at the national sphere of government prescribe a framework within which the preferential procurement policy must be implemented. Procurement by the organs of state (national and provincial departments, municipalities, constitutional entities and public entities) is also governed by a number of other pieces of legislation (Ambe \& BadenhorstWeiss 2012:247), which will be discussed in detail below. Section 217 (1) makes a provision for the procurement system to be fair, equitable, transparent, competitive and cost effective. However, without transparent and accountable systems, the vast resources acquired through the public procurement mode become susceptible to corruption and misuse of funds.

\section{Public Finance Management Act, 1999}

Section 76 (4) (c) of the Public Finance Management Act, 1999 (Act 1 of 1999) mandates the National Treasury to develop regulations or issue instructions regarding the determination of a framework for an appropriate procurement and provisioning system which is fair, equitable, transparent, competitive and cost effective (Republic of South Africa 1999; Watermeyer 2011:3). This provision has been drawn from Section 217 of the 1996 Constitution. Generally, the Act establishes a regulatory framework for public sector procurement, which includes procurement in the national 
and provincial departments and state-owned enterprises. Section 38 of the Public Finance Management Act, 1999 (Act 1 of 1999) also provides that accounting officers of a state department must inter alia ensure that the department has and maintains effective, efficient and transparent systems of financial and risk management, and internal control; a system of internal audit under the control and direction of an audit committee; and an appropriate procurement and provisioning system (Republic of South Africa 1999; Webb 2010:675). The accounting officer must take effective and appropriate steps to prevent unauthorised, irregular (including corruption), fruitless and wasteful expenditure and losses resulting from criminal conduct.

\section{Municipal Finance Management Act, 2003}

Local government: Municipal Finance Management Act, 2003 (Act 56 of 2003) also provides a regulatory framework for procurement at municipalities and municipal entities in South Africa. Local government sphere of government is often vulnerable to corruption particularly during the procurement process. Munzhedzi (2013:281) also postulates that the South African local government sphere is often characterised by service delivery failures, poor audit outcomes and financial management challenges including corruption.

\section{Prevention and Combating of Corrupt Activities Act, 2004}

It is the Prevention and Combating of Corrupt Activities Act, 2004 (Act 12 of 2004) that makes corruption and related activities an offence; establishes a register in order to place certain restrictions on persons and enterprises convicted of corrupt activities relating to tenders and contracts; and places a duty on certain persons holding a position of authority to report certain corrupt transactions (Ambe \& BadenhorstWeiss 2012:249). Chapter 5 of the Prevention and Combating of Corrupt Activities Act, 2004 (Act 12 of 2004) provides for the penalties relating to corrupt offences, as well as the establishment of a register for tender defaulters. Penalties range from imprisonment for a period not exceeding 3 years to imprisonment for life depending on whether the conviction is imposed by a magistrate, regional or high court, including the option to impose a fine (Webb 2010:677). The court may also order that the particulars of a convicted person or enterprise, in accordance with Sections 12 and 13 of the Act, be recorded in the register for tender defaulters. Furthermore, Section 28 determines that the government is prohibited from entering into any agreement with such convicted person or enterprise. The introduction of this Act was necessary to address issues of corruption, but the existing literature shows that corruption through the public procurement has been on the rise in the South African public sector.

\section{Preferential Procurement Policy Framework Act, $\mathbf{2 0 0 0}$}

Preferential Procurement Policy Framework Act, 2000 (Act 5 of 2000) establishes the manner in which preferential procurement policies are to be implemented (Ambe \&
Badenhorst-Weiss 2012:249). This Act gives effect to Section 217(3) of the 1996 Constitution by providing for a framework for the implementation of preferential procurement policy (Moeti 2014:155). Generally, this policy framework emphasises the preference of the previously disadvantaged majority, which includes black, mixed race and Indian people.

\section{Public Service Act, 1994}

Chapter VI of the Public Service Act, 1994 (Proclamation 103 of 1994) specifically deals with the inefficiency and misconduct in the public service including corruption through public procurement. Section 20 of the Act refers to misconduct as a behaviour that could inter alia incorporate acts that are to the prejudice of the administration, discipline and efficiency of a department, the acceptance or demand of any commission, fee or pecuniary or other reward in respect of carrying out or the failure to carry out official duties and any contravention of the prescribed code of conduct or any provision thereof (Republic of South Africa 1994). Furthermore, Sections 21-26 of the Public Service Act, 1994 (Proclamation 103 of 1994) offer the disciplinary procedure to be followed during a charge of misconduct as well as possible penalties in the event of a successful conviction. Such penalties include a fine not exceeding 6000 South African rand, the reduction of the official's salary or grade or both salary and grade to the extent recommended and discharge from the public service from a date to be determined by the head of the department (Webb 2010:675). Section 27 of the Act specifically addresses the handling of misconduct of a head of department who is the accounting officer in terms of the Public Finance Management Act, 1999 .

\section{Public Service Regulations of 2001}

Chapter two of the Public Service Regulations of 2001 includes the code of conduct, which issues guidelines for the conduct of public officials inter alia public officials' relationship with the legislature and the executive, the public and other employees, as well as the performance of their official duties and the conduct of their private interests. The code of conduct prohibits an employee from using his or her official position to obtain gifts and benefits for himself or herself during the performance of his or her official duties; obliges an official to report corruption, fraud, nepotism and maladministration to the appropriate authorities; requires an official to avoid any official action or decision-making process that would result in improper personal gain; and requires an official not to favour relatives and friends in work-related activities and never abuse his or her authority (Republic of South Africa 2001). These regulations go against anything unethical, improper, criminal, fraudulent and corrupt.

Chapter three of the Public Service Regulations, 2001 requires senior managers (equivalent of a director) in the public service to declare their personal financial interests in private or public companies, directorships and partnerships, ownership in land and property, and gifts and hospitality received (Public Service Commission 2013:73). If ever a 
possible conflict of interest does exist, various steps may be taken including disciplinary measures (Webb 2010:676). Any senior manager who fails to disclose such interests may be found guilty of misconduct. Unfortunately, compliance with the policy by senior managers is still not sufficient, with $68 \%$ in the $2010 / 2011$ and $75 \%$ in the $2011 / 2012$ financial years, respectively (Public Service Commission 2013:73).

\section{Pillars of public sector procurement}

All the legislative measures, including the aforesaid legislative framework, incorporate five core principles of behaviour or Five Pillars of Procurement upon which the entire SCM policy of effective and efficient municipal and government procurement is based. They include the following:

- Value-for-money: Refers to cost-effectiveness in the procurement system by providing value-for-money service, for example, the avoidance of unnecessary costs and delays for a department or its suppliers, as well as the monitoring of contracts to make sure they provide the anticipated benefits.

- Open and effective competition: Refers to the transparent, standardised and easily available laws, policies, practices and procedures that came into place. The practice must be open to public scrutiny.

- Ethics and fair dealings: Refers to fair dealings with all suppliers, abolition of prejudices, the elimination of fraud and corruption, as well as the non-acceptance of gifts or hospitality that could compromise the good standing of a municipality or the State.

- Accountability and reporting: Refers to the accountability of all concerned through openness and transparency. Everybody including politicians and administrative officials must be held accountable.

- Equity: Refers to the advancement of persons or categories of persons previously disadvantaged by unfair discrimination. The Preferential Procurement Policy Framework Act, 2000 (Act 5 of 2000) seeks to ensure the government's commitment to preferential procurement, economic growth by supporting industry but more specifically small, medium and micro enterprises (SMMEs); historically disadvantaged individuals (HDIs); the creation of opportunities for women and the physically disabled, as well as support for procuring local products (Horn \& Raga, 2012:78; National Treasury 2012:2).

The foregoing pillars of public procurement seek to eliminate some of the anomalies of corruption in the government. If these pillars could be used as a rule book, there can be an enormous improvement in addressing corruption in the public sector procurement. The so-called obvious association between procurement and corruption in the public sector could be efficiently addressed.

\section{State of corruption in the South African public sector}

According to the Public Service Commission (PSC) (2013:14), an enormous number of cases relating to fraud and corruption have been reported to the commission in the financial year $2012 / 2013$. The capacity of PSC as well as the respective public sector institution to deal with investigations of reported cases of alleged fraud and corruption by government officials is limited. As a result of lack of capacity, the effectiveness of the commission and government in its entirety is undermined. As indicated elsewhere in the article, reported cases are largely associated with public sector procurement.

A total of 2202 government officials were found guilty of misconduct related to corruption activities between September 2004 and March 2013 (Public Service Commission 2013:18). It shows the severity of corruption cases in the government. Because of the very issue of capacity, 1963 cases of corruption were referred to the government departments and public entities by the PSC. The commission often refers to lack of evidence and relevant information to proceed with majority of the reported cases. In essence, most perpetrators of corruption through public sector procurement tend to get away without being punished. Even though Balkaran (2013:141) indicates that the government has expressed determination to address the challenge of corruption in the public sector, Munzhedzi (2013:283) posits that there is a lack of commitment in the public sector, particularly the political leadership. However, Balkaran (2013:141) later concurs with Munzhedzi by providing that 'people have lost faith in the whole government system in that nothing gets done after reporting the alleged cases of fraud and corruption'. South Africa has not performed well in addressing fraud, corruption and financial misconduct over the years (Balkaran 2013:141; Sisulu \& Du Plessis 2013). It could be safely said that public sector procurement and corruption are surely like inseparable twins.

\section{Recent corruption cases relating to public procurement}

As indicated above, most corruption cases in the public sector are linked to procurement. To give credence to this view, below are some of the widely reported corruption cases that emanated from public procurement.

- A corruption investigation found that former police chief General Bheki Cele and a government minister were involved in property deals that were 'improper, unlawful, and amounted to maladministration' (Media24 2014).

- Former Communications minister Dina Pule laundered a R6-million gift of taxpayers' money to her boyfriend, lied publicly about their relationship and had her department to pick up her boyfriend's tab for lavish overseas trips, knowing he was not entitled to such perks (Media24 2014).

- The Public Protector found that the former Minister of Agriculture Tina Joematt-Pettersson wasted taxpayers' money, behaved unethically and tried to interfere in an investigation into alleged misconduct by her and her department relating to an R800-million tender in which the tender award process showed evidence of collusive tendering and/or bid rigging (Public Protector SA 2012/2013). 
- It has also been found that the former EThekwini mayor Obed Mlaba's family was linked to a R3-billion alleged tender 'hijack' in Durban (Media24 2014).

The foregoing are just but a few cases of public sector corruption that are linked to procurement. There are a whole lot of cases not mentioned including the Arms Deal and the 'Nkandla Gate', which are currently going through the Commission of Inquiry and parliamentary processes, respectively. It is the view of this author that if the link between public sector procurement and corruption is not adequately addressed, then the challenge will destroy the state's service delivery ability because it makes a huge dent in the public purse.

\section{Chief procurement officer}

The office of the chief procurement officer has been established with a particular view of reviewing high-value and strategic contracts to ensure that value-for-money is derived and that all contracts adhere to the relevant legislative prescripts (Gordhan 2014:28). Gordhan, who was minister of finance at the time (2009-2014), alludes that the review contributes to the efforts to ensure that government's service delivery objectives are supported by the appropriate purchases of goods and services. Other reasons for the establishment of the chief procurement office include the following:

- Review of big contracts, government leases and infrastructure projects such as the Passenger Rail Agency of South Africa (PRASA). PRASA is in a process of purchasing new locomotives to replace the old and outdated ones that are currently being used. It has a contract for R51 billion to replace commuter trains and coaches.

- Review South African Airway's (SAA's) fleet procurement process as part of the drive to streamlining government processes.

- Development of a standard lease agreement to address defects in government property transactions.

- Standardisation of infrastructure procurement processes and documentation.

- Creation of an inspectorate to monitor procurement plans and audit tender documents.

- Enhanced processing of vendors' tax clearance certificates to ensure compliance. There are cases of companies doing business with government whilst not being tax compliant (Knipe et al. 2002:298).

- Centralised procurement of health equipment, drugs and medicines to effect savings.

- Analysis of the business interests of government employees, which often results in the conflict of interest (Kuye \& Mafunisa 2003:427).

The foregoing objectives of the chief procurement officer are a positive initiative by the government. The main reason the office was introduced is because of the enormous challenges experienced by individual government departments, municipalities and public entities including corruption, lack of skills and capacity. Gordhan (2014:28) indicates that government is still mindful of the importance of government procurement in supporting local industry and black economic development. However, the effectiveness of the office of the chief procurement officer as to whether it can address some of the anomalies associated with public sector procurement such as corruption still has to be seen.

\section{Conclusion and recommendations}

The review of the existing literature has revealed that there is a general agreement between academics, practitioners and politicians that public procurement is vulnerable to corruption, maladministration and mismanagement. Various reasons have been provided for this occurrence, including political interference, the appointment of inexperienced and unqualified officials and contractors, qualified technical and professional experts who are not members of the respective bid committees, ignorance and lack of knowledge and capacity, noncompliance with the relevant legislative framework, unethical behaviour and decentralisation of public procurement (Ambe \& Badenhorst-Weiss 2012: 249-250; Horn \& Raga 2012:89-90; Munzhedzi 2013:284). The relationship between public sector procurement and corruption is so intimate that they are like inseparable twins. However, the article concludes that it is possible to address the said challenges of public procurement including corruption.

The government of the day ought to be decisive in order to deal with corruption as one of the challenges confronting public sector procurement in the Republic of South Africa. Government must always ensure that noncompliance with the legislative framework by SCM officials is punishable as prescribed by both Public Finance Management Act, 1999 (Act 1 of 1999) and Municipal Finance Management Act, 2003 (Act 56 of 2003). To succeed in the battle against corruption in the public sector procurement, officials who contravene rules must be arrested, tried and jailed. Mafunisa (2013:751) put it precisely that 'corrupt actors must be named and punished so that a cynical citizenry believes that an anti-corruption drive is more than words'. These actors could either be politicians or administrators at all levels of the government, particularly at the senior level.

However, it is also important to ensure accountability by politicians and officials, particularly the accounting officer and the SCM officials. Accountability borders on the mainstream of ethics, which Socrates (regarded as the founder of moral philosophy) viewed as the rational way that a thoughtful man could follow in order to achieve morality (Ababio 2007:5). Vyas-Doorgapersad and Ababio (2006:386) state that accountability can be understood as the answerability for performance and the obligation that public functionaries (elected office bearers and appointed officials) have to give a satisfactory explanation to the public (tax payers) concerning the exercise of power, authority and resources entrusted to them. On the other hand, it is paramount to ensure that interference of politicians on procurement is limited because it often results in conflict of interest. Horn and Raga (2012:88) posit that clarity is needed between the roles of politicians and administrators. 
Capacitation of SCM units is recommended to address some of the inadequacies regarding skills and knowledge. Regular workshops, during which the legislative prescripts are explained, can assist in overcoming skills and knowledge capacities (Horn \& Raga 2012:88). The capacitation may take the form of comprehensive training, conducting workshops or awarding university bursaries to government employees to be trained for at least 3 years. The less expensive method though is ensuring that all public sector institutions recruit and appoint qualified and experienced personnel. It must be noted that this might be difficult to implement particularly with rural municipalities, which cannot afford these qualified and experienced recruits. Rural municipalities often cannot afford to pay scarce skills practitioners including engineers, chartered accountants, land surveyors and quantity surveyors. They hire them as consultants instead.

Promotion of ethical leadership in the public sector is also paramount. Ethics refers to moral principles that govern a person's behaviour or conduct. Rasheed and Olowu (1993:44) argue that the unethical conduct known to exist in Africa starts at the top of the political and public service leadership. An ethical framework forms the basic set of standards for behaviour in society or any sector. The existence of such a programme would mean that people would know what is right and what is wrong because they are able to measure conduct against a formal or informal set of ethical standards (Department of Public Service and Administration 2003:9). Mafunisa (2013:761) also posits that the manifestations of unethical and irresponsible behaviour by senior public functionaries not only reduce the morale of many committed junior public servants but also negatively influence others in engaging themselves in similar practices.

\section{Acknowledgements}

\section{Competing interests}

The author declares that he has no financial or personal relationships which may have inappropriately influenced him in writing this article.

\section{References}

Ababio, E., Vyas-Doorgapersad, S. \& Mzini, L., 2008, 'Service delivery and underexpenditure: Strategies towards effective control of public funds', Journal of Public Administration 43(3.1), 3-15

Ababio, E.P., 2007, 'Bloodhounds on municipal financial management: What goes awry?', Journal of Public Administration 42(5), 3-14.

Ambe, I.M. \& Badenhorst-Weiss, J.A., 2012, 'Procurement challenges in the South African public sector', Journal of Transport and Supply Chain Management 46(3) 242-261.

Arrowsmith, S., 2010, Public procurement: Basic concepts and the coverage of procurement rules, in Public procurement relations: An introduction, EU Asia procurement rules, in Public procur
InterUniversity Network, Brussels.

Balkaran, S., 2013, 'A captured mind is a captured state: The South African public service', International Conference on Development Finance and Transformation's Conference Proceedings, October 2013, Polokwane, pp. 129-145.

Bolton, P., 2006, 'Government procurement as a policy tool in South Africa', Journal of Public Procurement 6(3), 193-217.

Department of Public Service and Administration, 2003, Country corruption assessment report, DPSA, Pretoria, South Africa.

Douglas, R. \& Jones, M., 1996, Administrative law: Commentary and materials, Federation Press, Annandale.
Gordhan, P., 2014, Budget speech, National Treasury, Cape Town.

Hanks, J., Davies, H. \& Perera, O., 2008, Sustainable public procurement in South Africa, viewed 30 March 2014, from https://www.iisd.org/pdf/2008/spp_south_ africa.pdf

Horn, G.S. \& Raga, K., 2012, 'Municipal supply chain management challenges and solutions: An empirical study', Administratio Publica 20(3), 71-91.

Jeppesen, R., 2010, Accountability in public procurement: Transparency and the role of civil society, United Nations Procurement Capacity Development Centre, viewed 07 March 2014, from http://unpcdc.org/media/142496/story\%20of\%20 an\%20institution\%20-\%20accountability.pdf

Khalo, T., 2014, Municipal financial management, in G. Van Der Waldt (ed.), Municipal management: Serving the people, pp. 226-250, Juta, Claremont, CA.

Klitgaard, R., Maclean-Abaroa, R. \& Lindsey Parris, H., 2000, Corrupt cities: A practical guide to cure and prevention, Institute for Contemporary Studies \& World Bank Institute, Pretoria.

Knipe, A., Van Der Waldt, G., Van Niekerk, D., Burger, D. \& Nell, K., 2002, Project management for success, Heinemann, Sandown.

Kuye, J.O. \& Mafunisa, M.J., 2003, 'Responsibility, accountability and ethics: The case for public service leadership', Journal of Public Administration 38(4), 421-437.

Madumo, S.O., 2012, 'The promotion of developmental local government to facilitate a developmental state', Administratio Publica 20(3), 40-54.

Mafunisa, M.J., 2013, 'Role of leadership in creating commitment in the public service', Journal of Public Administration 48(4.1), 751-763.

Mahlaba, P.J., 2004, 'Fraud and corruption in the public sector: An audit perspective', Service Delivery Review 3(2), 84-87.

Mahmood, S.A.I., 2010, 'Public procurement and corruption in Bangladesh: Confronting the challenges and opportunities', Journal of Public Administration and Policy Research 2(6), 103-111.

Media24, 2014, 'The A - Z of SA's fraud \& corruption scandals', viewed 18 June 2015, from http://www.news24.com/MyNews24/The-A-Z-of-SAs-Fraud-CorruptionScandals-20140403

Moeti, K. (ed.), 2014, Public finance fundamentals, 2nd edn., Juta, Cape Town.

Munzhedzi, P.H., 2013, 'Financial viability of the South African municipalities: Some observations on legal compliance', International Conference on Development Finance and Transformation's Conference Proceedings, October 2013, Polokwane, pp. 281-292.

National Treasury, 2012, National Treasury General Procurement Guidelines, National Treasury, Pretoria.

Pauw, J.C., 2011, Public procurement and supply chain management, Public Procurement and Supply Management Study Guide, Centre for Business Management, University of South Africa, Pretoria, South Africa.

Pauw, J.C., Woods, G., Van Der Linde, G.T.A., Fourie, D. \& Visser, C.B., 2002, Managing public money: Systems from the south, Heinemann Publishers (Pty) Ltd.

Pope, J., 2000, Confronting corruption: The elements of a national integrity system, Transparency International, Berlin.

Public Protector SA, 2012/13, Costly moves: A report of the public protector on an investigation into the allegations of a breach of the executive ethics code by the Minister of Agriculture, Forestry and Fisheries, Ms T Joemat-Pettersson, Public Protector SA, Pretoria.

Public Service Commission, 2013, Annual report 2012/2013, Public Service Commission, Pretoria.

Rasheed, S. \& Olowu, D. (eds.), 1993, Ethics and accountability in African public services, AAPAM, Addis Ababa.

Reddy, P.S., Naidoo, P. \& Pillay, P., 2005, 'Local democracy and developmental local government in South Africa beyond the first decade: Quo vadis?', Africanus 35(2), $40-52$.

Shamsul Haque, M., 2001, 'The diminishing publicness of public service under the current mode of governance', Public Administration Review 61(1), 65-82.

Sisulu, L. \& du Plessis, C., 2013, Getting servants to serve, City Press, Johannesburg.

Republic of South Africa, 1968, State Tender Board Act, 1968 (Act 86 of 1968), Government Printers, Pretoria.

Republic of South Africa, 1994, Public Service Act, 1994 (Proclamation 103 of 1994), Government Printers, Pretoria.

Republic of South Africa, 1996, Constitution of the Republic of South Africa, 1996, Government Printers, Pretoria.

Republic of South Africa, 1999, Public Finance Management Act, 1999 (Act 1 of 1999), Government Printers, Pretoria.

Republic of South Africa, 2000, Preferential Procurement Policy Framework Act, 2000 (Act 5 of 2000), Government Printers, Pretoria.

Republic of South Africa, 2001, Public Service Regulations of 2001, Government Printers, Pretoria.

Republic of South Africa, 2003, Local Government: Municipal Financial Management Act, 2003 (Act 56 of 2003), Government Printers, Pretoria.

Republic of South Africa, 2004, Prevention and Combating of Corrupt Activities Act, 2004 (Act 12 of 2004), Government Printers, Pretoria.

Rose-Ackerman, S., 1999, Political corruption and democracy, Yale Law School, New Haven, CT.

Smart Procurement, 2011, SA public procurement: Poor value for money, viewed 10 February 2014, from http://www.smartprocurement.co.za/archives/sa_public procurement_-_poor_value_for_money.php 
Stapenhurst, F. \& Langseth, P., 1997, 'The role of the public administration in fighting corruption', International Journal of Public Sector Management 10(5), 311-330.

Thornhill, C., 2006, 'Effective municipal government and administration as preconditions for efficient service delivery', Journal of Public Administration, Conference proceedings September, 317-332.

Thornhill, C., 2012, 'Improving local government transformation in South Africa', Administratio Publica 20(3), 128-143.
Vyas-Doorgapersad, S. \& Ababio, E.P., 2006, 'Ethical dilemmas and democratic values: How to reposition institutions for good governance and increased service delivery', Journal of Public Administration 41(2.2), 385-396.

Watermeyer, R.B., 2011, 'Regulating public procurement in Southern Africa through international and national standards', Public procurement regulation in Africa Conference, 25 October, Stellenbosch.

Webb, W., 2010, 'Public management reform and the management of ethics: Incompatible ideals for the developing state?', International Journal of Public Sector Management 23(7), 669-684. 